\title{
Organizations of public benefit: performance evaluation using MCDA approach
}

\author{
Dorota Górecka $^{1, \dagger}$ and Ewa Chojnacka ${ }^{2}$ \\ ${ }^{1}$ Department of Econometrics and Statistics, Faculty of Economic Sciences and \\ Management, Nicolaus Copernicus University in Toruń, ul. Gagarina 13A, 87-100 \\ Toruń, Poland \\ E-mail: 〈dgorecka@umk.pl 〉 \\ ${ }^{2}$ Department of Financial Accounting, Faculty of Economic Sciences and Management, \\ Nicolaus Copernicus University in Toruń, ul. Gagarina 13A, 8\%-100 Toruń, Poland \\ E-mail: 〈echoj@umk.pl 〉
}

\begin{abstract}
In many countries, organizations of public benefit play an important role in the economy and are established only for charitable purposes. Serving the public interest is often connected with certain benefits, such as additional source of revenue, tax advantages or state grants, but also certain obligations, such as guaranteeing trustworthiness and transparency of operations. Taking the role of charities and voluntary organizations into consideration there is a great need to assess properly such entities whereas tools indicated for corporate finance are not appropriate since these units are established for purposes other than profit-making. Moreover, their range of activities is very different. Hence, new assessment methods are needed in order to evaluate them properly. For this reason the main aim of this paper is to propose and apply multi-criteria decision aiding (MCDA) approach to the problem of assessment of organizations of public benefit. The proposed procedure using EVAMIX method for mixed evaluations (deterministic and stochastic) has been employed in the process of appraising and ranking nine Public Benefit Organizations (PBOs) from one of Polish voivodships operating in the field of 'Ecology, animals and heritage protection', and eight charities from two neighboring English metropolitan boroughs, operating in the field of 'Animals'. Rankings of these entities have been obtained so that, e.g., a potential donator would have a better base to make his or her decision regarding financial support.
\end{abstract}

Keywords: public benefit organizations, charities, performance evaluation, PBOs reporting, MCDA, EVAMIX method for mixed evaluations

Received: September 30, 2016; accepted: December 20, 2017; available online: December 30,2017

DOI: $10.17535 /$ crorr. 2017.0040

\footnotetext{
${ }^{\dagger}$ Corresponding author 


\section{Introduction}

Charities and voluntary organizations exist all over the world and their number is constantly increasing. In the economy, they represent the third sector and are also labeled as non-profit sector, non-profit organizations (NPOs) and non-governmental organizations (NGOs). In many countries, third sector organizations play an important role by carrying out certain tasks that are believed to be of general benefit to society. Their operating scope may be very diverse and their activity may affect ecology, sport, education, health issues, culture and many other fields. The economic impact of the third sector is validated by many studies, which make an attempt to present the relative impact of this sector on certain statistical economic measures, such as employment or GDP [37]. In 2013 the nonprofit sector contributed an estimated 905.9 billion dollars to the U.S. economy, what constitutes $5.4 \%$ of the country's GDP [22]. Unfortunately, statistical data concerning the third sector in different countries is often incomparable. On one hand, it stems from non-unified national definitions of the third sector which include a great variety of economic entities. The understanding of the third sector scope varies across Europe, going from the narrow concept based on the legal tradition of the Charities Act in the United Kingdom, to very broad ideas of social economy and third sector popular in other parts of the continent [28]. On the other hand, the lack of data comparability can also be rooted in the lack of full and appropriate understanding of the third sector's contribution to the economy.

Considering that the third sector plays such an important role in the economy, some initiatives have been taken to obtain reliable statistical data. Let us mention the initiatives started by the Third Sector Research Centre and the National Council of Voluntary Organizations, the Johns Hopkins Center for Civil Society Studies or the Third Sector Impact project [37]. The latter started in 2014 and is financed by European Union. Its main aim is to recognize "the scope and scale of the third sector in Europe, its current and potential impact, and the barriers hindering the third sector to fully contribute to the continent's welfare" [30]. One of the first effects of this project is a consensus conception of the third sector in EU (more in [28]).

In many countries, certain entities classified as third sector organizations also become public benefit organizations (PBO). In most continental European countries, recognizing a given third sector organization to be of 'public benefit' means that the organization has obtained a special 'status' after being registered as a legal entity (usually in the form of an association or a foundation). The approach to public benefit is different in the United Kingdom, where all organizations with solely public benefit purposes are considered 'charities' [23]. Introducing a public benefit organization (PBO) status as well as strengthening accountability requirements for $\mathrm{PBOs}$ and overall promotion of accountability and transparency of NPO are perceived among the key trends in regulations concerning non-profit 
organizations. These trends are connected with three major factors, i.e. the increased economic and policy importance of the sector, the aspiration of governments to optimize NPO contributions to the public good, and efforts made by the NPOs in order to reinforce the confidence and increase the support of the public [2].

Taking into consideration the role of public benefit organizations/charities we can see a great need to properly assess such entities. Their importance for the economy, represented for example by the volume of funds they control, requires monitoring their operations [36]. For example the average income generated by charities operating in Great Britain in 2015 was 426.3 thousand pounds whereas the average turnover in SME in 2015 amounted about 325.9 thousand pounds [3; 26]. Thus, it is very important to indicate the organizations which have obtained the highest 'social return on investment' [6]. These organizations need to try to measure their activities as to demonstrate their competency, to achieve legitimacy, and to obtain funding [1]. Unfortunately, tools indicated for corporate finance are not appropriate in this case since these entities are established for purposes other than profit-making. Moreover, their range of activity is quite diversified, which makes the assessment process even more complicated. Therefore, new assessment methods are needed in order to properly evaluate organizations of public benefit, so that both financial and non-financial information would be included in the performance assessment of $\mathrm{PBO}$.

In the forgoing context the aim of this paper is to propose and apply multi-criteria decision aiding (MCDA) approach based on the outranking relation to the problem of assessment of public benefit organizations. Considering the specific economic situation of these entities, a set of special measures will be used in the analysis. Some of those measures have already been presented in literature [36; $35 ; 34 ; 7 ; 6]$, while others have been constructed for the purpose of this paper. The use of MCDA approach allows for obtaining what may be called a ranking of the effectiveness and reputation of public service organizations. This type of performance assessment may serve potential individual and institutional donators as a base for making their decisions. Furthermore, organizations of public benefit often obtain funds from public subsidies as a result of competition among these organizations. In our opinion, this approach may be used by the authorities as a tool of assessing public benefit organizations which have to compete for public resources. Finally, non-profit organizations could be interested in evaluating their position in comparison to other such institutions. Such an evaluation would be an opportunity to verify the organization's attractiveness as a fundraiser in the growing competitive reality of the third sector. The usefulness of the approach we proposed will be illustrated, using an example of Public Benefit Organizations from one of Polish voivodships, operating in the field of 'Ecology, animals and heritage protection', as well as with an example of charities from two neighboring English metropolitan boroughs, operating in the field of 'Animals'. 
The article contains five chapters. Following the Introduction, in section 2 we present a short comparison of selected characteristics of public benefit status in Great Britain and in Poland. The third and the fourth part, in turn, include the description of the proposed procedure and the case study as well as the solutions obtained as a result of applying the MCDA tool. We conclude by summarizing the key concept of our approach, considering its certain shortcomings and discussing briefly the future work.

\section{Organizations of public benefit in Great Britain and in Po- land}

The organizations which were chosen to be assessed using MCDA methods operate in Great Britain and in Poland. They are subject to two major legal systems: the common law system used in Great Britain and the civil law system which is used in Poland. Having chosen organizations which are subject to two different legal systems should facilitate our attempt to propose universal approach which can be applied in organizations of public benefit, regardless of the domestic legal requirements regulating their activity.

In Europe, Great Britain has a long tradition of charity organizations activities. The first law regulation, Charitable Uses Act (known as the Statute of Elizabeth) was implemented in 1601. Today, the definition of a charity can be found in the Charities Act. According to The Charities Act 2011, a charity is an institution which is established only for charitable purposes and each of its purposes must be for the public benefit ('the public benefit requirement') [28]. Currently in Great Britain the number of charities is rather stable. The Charity Commission announced that 165,290 charities operated as at the end of 2015 (in 2004 the total number of charities was 166,336$)$ [3].

In Poland, vast majority of currently functioning NPOs were set up after the collapse of the communist system in 1989. The former period, i.e. the years following World War II, were unfavorable to voluntary organizations due to political and administrative control. Many NPOs were dissolved or liquidated [21]. However, public benefit organizations have only been operating in Poland since 2003, when the Law on Public Benefit Activity and Volunteer Work Act was introduced. According to this act of law, PBOs are mostly non-governmental organizations defined as corporate and non-corporate entities which obtained the public benefit status, not forming part of the public finance sector and not operating for profit purpose. In Poland, the situation is quite dynamic, as the number of PBO entities has risen from 2,200 to 8,700 in the period of 2004-2014 [10]. Table 1 presents selected characteristics of charities in Great Britain and PBOs in Poland. 


\begin{tabular}{|c|c|c|}
\hline Characteristic & $\begin{array}{c}\text { United Kingdom } \\
\text { (a common-law country) } \\
\text { Charities }\end{array}$ & $\begin{array}{c}\text { Poland } \\
\text { (a civil-law country) } \\
\text { Public Benefit Organizations }\end{array}$ \\
\hline $\begin{array}{l}\text { Criteria for } \\
\text { obtaining } \\
\text { public benefit } \\
\text { status }\end{array}$ & $\begin{array}{l}\text { Organizations established } \\
\text { only for charitable purposes } \\
\text { (a list of } 12 \text { particular } \\
\text { purposes). } \\
\text { Each of its purposes must } \\
\text { concern public benefit (there } \\
\text { are five main principles } \\
\text { which show whether an } \\
\text { organization provides benefit } \\
\text { to the public). }\end{array}$ & $\begin{array}{l}\text { Regulations provide a list of } \\
\text { organizations that cannot } \\
\text { apply for PBO status (e.g. } \\
\text { political parties). } \\
\text { PBOs must engage } \\
\text { exclusively in public benefit } \\
\text { activities (they may run } \\
\text { commercial activity, but only } \\
\text { as an addition to public } \\
\text { benefit activity). } \\
\text { An entity must have been } \\
\text { operating without } \\
\text { interruption for at least } 2 \\
\text { years. }\end{array}$ \\
\hline Registration & $\begin{array}{l}\text { Charities are registered by } \\
\text { the Charity Commission. }\end{array}$ & $\begin{array}{l}\text { PBOs are registered in the } \\
\text { National Court Register. }\end{array}$ \\
\hline Legal forms & $\begin{array}{l}\text { Main types: charitable } \\
\text { incorporated organization } \\
\text { (CIO), charitable company } \\
\text { (limited by guarantee), } \\
\text { unincorporated association, } \\
\text { trust. }\end{array}$ & $\begin{array}{l}\text { Primarily association and } \\
\text { foundation. }\end{array}$ \\
\hline $\begin{array}{l}\text { Benefits } \\
\text { for the } \\
\text { organization }\end{array}$ & $\begin{array}{l}\text { Tax benefits on most of the } \\
\text { income and gains if it is used } \\
\text { for charitable purposes } \\
\text { (includes tax on donations, } \\
\text { on profits from trading, on } \\
\text { rental or investment income, } \\
\text { on profits when you sell or } \\
\text { 'dispose of' an asset, like } \\
\text { property or shares, when you } \\
\text { buy property). } \\
\text { Many sources of grants, } \\
\text { including the National } \\
\text { Lottery, are available more } \\
\text { easily, or exclusively, to } \\
\text { charities. }\end{array}$ & $\begin{array}{l}\text { Tax benefits (corporate } \\
\text { income tax exemption on all } \\
\text { income } \\
\text { used on statutory activity, } \\
\text { exemption from real estate } \\
\text { tax, civil actions tax, stamp } \\
\text { duty and court fees). } \\
\text { The } 1 \% \text { law (taxpayer may } \\
\text { allocate } 1 \% \text { of their tax } \\
\text { payment for the sake of } \\
\text { public benefit organizations } \\
\text { they chose). } \\
\text { Preferential terms while } \\
\text { using public property; } \\
\text { promotion in public media is } \\
\text { free of charge. }\end{array}$ \\
\hline
\end{tabular}




\begin{tabular}{|c|c|c|}
\hline $\begin{array}{l}\text { Reporting } \\
\text { obligations }\end{array}$ & $\begin{array}{l}\text { Charities with an income } \\
\text { over } £ 10,000 \text { must submit } \\
\text { an annual return. Those } \\
\text { below the threshold need } \\
\text { only make reports available } \\
\text { for inspection. Charities with } \\
\text { an income over } £ 25,000 \\
\text { must submit a PDF copy of } \\
\text { their accounts, an } \\
\text { independent examiner or } \\
\text { auditor's report and the } \\
\text { trustees' annual report (a } \\
\text { detailed report is required if } \\
\text { charity's gross income } \\
\text { exceeds } £ 500,000 ; \text { otherwise } \\
\text { a brief summary is needed). } \\
\text { The commission displays on } \\
\text { its website trustees' annual } \\
\text { reports that are sent to } \\
\text { them. }\end{array}$ & $\begin{array}{l}\text { PBOs are obliged to prepare } \\
\text { an annual performance report } \\
\text { and annual financial } \\
\text { statement. These reports are } \\
\text { publicly accessible, as they } \\
\text { must be published in the } \\
\text { Internet database of the } \\
\text { Ministry of Labor and Social } \\
\text { Policy. } \\
\text { PBOs are required to disclose } \\
\text { the information in how the } \\
1 \% \text { is used. }\end{array}$ \\
\hline
\end{tabular}

Sources: [28], [23], [38], [19]

Table 1: Certain characteristics of charities in Great Britain and PBOs in Poland

\section{The proposed procedure of appraising organizations of pub- lic benefit}

Meeting the need to develop the system of evaluation and selection of organizations of public benefit, for instance for private or public co-financing (donations), and taking into account advantages and disadvantages of different MCDA methods (see [11], [12] and [14]) as well as the fact that data used for assessment will be partly qualitative and partly quantitative, and, additionally, at least some performances of alternatives will be evaluated in a probabilistic way, the procedure composed of the following elements has been proposed to aid the decision-makers (DMs):

- Identification of the participants of the decision-making process;

- Selection of the performance evaluation criteria and measures for them;

- Determination of weights for evaluation criteria:

- arbitrarily;

- with the help of the Hinkle's method, which is also called the 'resistance to change' grid (see [16] and [27]); 
- $\quad$ with the help of the revised Simos' procedure (see [8]);

- $\quad$ using Hokkanen and Salminen's approach, version 1 or 2 (see [17] and [18]);

- $\quad$ using Mousseau's method (see [24]);

(the choice of the method depends on the number and preferences of the decision-makers);

- Collecting data and building a table of assessments (evaluation matrix) of organizations taken into consideration;

- Application of the EVAMIX method for mixed evaluations (see [5]), which is a hybrid of the EVAMIX method (see [32]) and the EVAMIX method with stochastic dominance rules (see [11] and [13]), to construct a ranking of the PBOs;

- Taking the final decision.

In the EVAMIX method, proposed by H. Voogd (see [32] and [33]), the qualitative and quantitative data are distinguished and the final appraisal score of a given alternative is the result of a combination of the evaluations calculated separately for the qualitative and quantitative criteria. After including stochastic dominance rules in this procedure, the EVAMIX method for mixed evaluations (deterministic and stochastic ones) consists of the following steps (see [5]):

1. Determination of the qualitative dominance measures for the ordinal criteria:

$$
\alpha_{i j}=\left[\sum_{k \in O}\left\{w_{k} \varphi_{k}\left(a_{i}, a_{j}\right)\right\}^{c}\right]^{\frac{1}{c}}, \quad c=1,3,5 \ldots
$$

where:

$c$ - an arbitrary scaling parameter, for which any positive odd value may be chosen; the higher the value of the parameter is, the weaker the influence of the deviations between the evaluations for the less important criteria, $O$ - a set of qualitative (ordinal) criteria ${ }^{\ddagger}$;

$$
\varphi_{k}\left(a_{i}, a_{j}\right)=\left\{\begin{array}{l}
1 \text { if } f_{k}\left(a_{i}\right)-f_{k}\left(a_{j}\right)>0 \\
-1 \text { if } f_{k}\left(a_{j}\right)-f_{k}\left(a_{i}\right)>0 \\
0 \text { otherwise }
\end{array}\right.
$$

for deterministic evaluations,

\footnotetext{
${ }^{\ddagger}$ It is assumed that all the criteria are maximized.
} 
$f_{k}\left(a_{i}\right)$ - performance of alternative $a_{i}$ on criterion $f_{k}$;

$$
\varphi_{k}\left(a_{i}, a_{j}\right)=\left\{\begin{array}{l}
1 \text { if } \mathrm{F}_{k}^{i} S D F_{k}^{j} \text { and } \mu_{k}\left(a_{i}\right)-\mu_{k}\left(a_{j}\right)>0, \\
-1 \text { if } F_{k}^{j} S D F_{k}^{i} \text { and } \mu_{k}\left(a_{j}\right)-\mu_{k}\left(a_{i}\right)>0, \\
0 \text { otherwise, }
\end{array}\right.
$$

for stochastic evaluations,

$F_{k}^{i}$ - distribution of the evaluations of alternative $a_{i}$ with respect to criterion $f_{k}$,

$\mu_{k}\left(a_{i}\right)$ - average performance (expected value of the evaluation distribution) of alternative $a_{i}$ on criterion $f_{k}$,

and $S D$ denotes stochastic dominance relation: OFSD/OSSD (see [29]), OAFSD/OASSD (see [12] and [13]).

2. Calculation of the quantitative dominance measures for the cardinal criteria:

$$
\gamma_{i j}=\left[\sum_{k \in Q}\left\{w_{k}\left(v_{k}\left(a_{i}\right)-v_{k}\left(a_{j}\right)\right)\right\}^{c}\right]^{\frac{1}{c}}, c=1,3,5 \ldots,
$$

for deterministic evaluations,

where:

$Q$ - a set of quantitative (cardinal) criteria ${ }^{\S}$, $v_{k}\left(a_{i}\right)$ - standardized performance of alternative $a_{i}$ on criterion $f_{k}$ (expressed on a scale from 0 to 1 );

$$
\gamma_{i j}=\left\{\begin{array}{l}
{\left[\sum_{k \in Q}\left\{w_{k}\left(\eta_{k}\left(a_{i}\right)-\eta_{k}\left(a_{j}\right)\right)\right\}^{c}\right]^{\frac{1}{c}}, c=1,3,5 \ldots, \text { if } F_{k}^{i} S D F_{k}^{j},} \\
0 \text { otherwise, }
\end{array}\right.
$$

for stochastic evaluations,

where:

$\S$ It is assumed that all the criteria are maximized. 
$\eta_{k}\left(a_{i}\right)$ - average standardized performance (expected value of the standardized evaluation distribution) of alternative $a_{i}$ on criterion $f_{k}$,

$F_{k}^{i}$-distribution function representing standardized evaluations of alternative $a_{i}$ with respect to criterion $f_{k}$,

and $S D$ denotes stochastic dominance relation: FSD/SSD (see [25] and [15]), AFSD/ASSD (see [20]).

3. Standardization of the dominance measures as follows:

$$
\begin{aligned}
& \delta_{i j}=\alpha_{i j}\left(\sum_{i=1}^{m} \sum_{j=1}^{m}\left|\alpha_{i j}\right|\right)^{-1}, \\
& \sigma_{i j}=\gamma_{i j}\left(\sum_{i=1}^{m} \sum_{j=1}^{m}\left|\gamma_{i j}\right|\right)^{-1} .
\end{aligned}
$$

4. Calculation of the overall dominance measure $q_{i j}$ for each pair of alternatives:

$$
q_{i j}=w_{O} \delta_{i j}+w_{Q} \sigma_{i j}
$$

where:

$w_{O}$ - the sum of weights of qualitative criteria,

$w_{Q}$ - the sum of weights of quantitative criteria.

5. Determination of the final appraisal score $u_{i}$ for each alternative:

$$
u_{i}=\frac{1}{m} \sum_{j=1}^{m} q_{i j}
$$

6. Ranking of the alternatives (PBOs) according to the descending order of the final appraisal scores. 


\section{Case study}

The present study illustrates the application of the proposed procedure in the process of appraising and ranking nine Public Benefit Organizations from one of Polish voivodships operating in the field of 'Ecology, animals and heritage protection', and eight charities from two neighboring English metropolitan boroughs, operating in the field of 'Animals'. Factors affecting the choice of the organizations of public benefit for donation have been identified through the literature review as well as based on the authors' own ideas. They are presented in Table 2.

\begin{tabular}{|c|c|c|c|}
\hline \multirow[b]{2}{*}{ No. } & \multirow{2}{*}{$\begin{array}{c}\text { Criterion } \\
\text { (min/max/value } \\
\text { of); } \\
\text { earlier studies }\end{array}$} & \multicolumn{2}{|c|}{ Measure - calculation formula } \\
\hline & & United Kingdom & Poland \\
\hline $\mathrm{f}_{1}$ & $\begin{array}{c}\text { Average amount of } \\
\text { aid per beneficiary } \\
(\max )\end{array}$ & $\begin{array}{c}\text { charitable activities }+ \\
\text { cost of generating } \\
\text { voluntary } \\
\text { income)/number of } \\
\text { beneficiaries } \\
\end{array}$ & $\begin{array}{c}\text { cost of unpaid } \\
\text { statutory } \\
\text { activities/number of } \\
\text { beneficiaries }\end{array}$ \\
\hline $\mathrm{f}_{2}$ & $\begin{array}{c}\text { Average revenue } \\
\text { generated by people } \\
\text { involved in } \\
\text { organization's } \\
\text { activities (max) }\end{array}$ & $\begin{array}{l}\text { total revenue/number } \\
\text { of people involved in } \\
\text { charity activities }\end{array}$ & $\begin{array}{l}\text { total revenue/number } \\
\text { of people involved in } \\
\text { PBO's activities }\end{array}$ \\
\hline $\mathrm{f}_{3}$ & $\begin{array}{l}\text { Labor cost in } \\
\text { relation to total } \\
\text { revenue (min) }\end{array}$ & \multicolumn{2}{|c|}{ gross salaries/total revenue } \\
\hline $\mathrm{f}_{4}$ & $\begin{array}{c}\text { Change in revenue } \\
\text { (max); } \\
{[4]}\end{array}$ & \multicolumn{2}{|c|}{$\begin{array}{l}\text { (total revenue in current year - total revenue in } \\
\text { previous year)/ total revenue in previous year }\end{array}$} \\
\hline $\mathrm{f}_{5}$ & $\begin{array}{c}\text { Financial stability } \\
\text { ratio (value of } 73 \text { ); } \\
{[6],[7]}\end{array}$ & $\begin{array}{l}\text { (cash at bank and in } \\
\text { hand }+ \text { other short- } \\
\text { term investments (in } \\
\text { previous } \\
\text { year) } * 365 / \text { total cost } \\
\text { (in current year) }\end{array}$ & $\begin{array}{l}\text { cash and other short- } \\
\text { term investments (in } \\
\text { previous } \\
\text { year) }{ }^{*} 365 / \text { total cost (in } \\
\text { current year) }\end{array}$ \\
\hline $\mathrm{f}_{6}$ & $\begin{array}{c}\text { Private revenue } \\
\text { concentration ratio } \\
\text { (\% of private } \\
\text { financing) } \\
(\max ) ; \\
{[6],[7]} \\
\end{array}$ & $\begin{array}{l}\text { (individual donations }+ \\
\text { fundraising }+ \\
\text { legacies)/total revenue }\end{array}$ & $\begin{array}{c}\text { (1\% of PIT }+ \text { incomes } \\
\text { from private sources } \\
\text { including individual } \\
\text { and institutional } \\
\text { donations)/total } \\
\text { revenue }\end{array}$ \\
\hline
\end{tabular}




\begin{tabular}{|c|c|c|c|}
\hline $\mathrm{f}_{7}$ & $\begin{array}{l}\text { Administrative } \\
\text { costs ratio (\% of } \\
\text { administrative } \\
\text { costs) (value of } \\
\quad 6.5 \% \text { ); } \\
{[6],[7],[9],[31]}\end{array}$ & $\begin{array}{l}\text { governance cost/total } \\
\text { cost }\end{array}$ & $\begin{array}{l}\text { administrative } \\
\text { cost/total cost }\end{array}$ \\
\hline $\mathrm{f}_{8}$ & $\begin{array}{l}\text { Activity scope } \\
\text { (value of } 36) \\
{[6],[7]}\end{array}$ & \multicolumn{2}{|c|}{$\begin{array}{c}\text { number of beneficiaries/number of people } \\
\text { involved in organization's activities }\end{array}$} \\
\hline $\mathrm{f}_{9}$ & $\begin{array}{l}\text { Alternative labor } \\
\text { costs }(\max ) ; \\
{[6],[7]}\end{array}$ & \multicolumn{2}{|c|}{ (number of volunteers* gross salaries)/employees } \\
\hline $\mathrm{f}_{10}$ & $\begin{array}{l}\text { Organization's age } \\
\qquad(\max ) \\
{[31]}\end{array}$ & $\begin{array}{l}\text { the number of days an } \\
\text { organization has been } \\
\text { active }\end{array}$ & $\begin{array}{l}\text { the number of days an } \\
\text { organization has PBO } \\
\text { status }\end{array}$ \\
\hline $\mathrm{f}_{11}$ & $\begin{array}{l}\text { Statutory goals and } \\
\text { activities or } \\
\text { projects }(\max ) \\
{[7]}\end{array}$ & \multicolumn{2}{|c|}{$\begin{array}{l}\text { Do annual statements of an organization or its } \\
\text { promotion materials define precisely statutory } \\
\text { goals and activities or projects undertaken to } \\
\text { achieve those objectives? } \\
\text { (appraisal of the DM on scale 0-3) }\end{array}$} \\
\hline $\mathrm{f}_{12}$ & $\begin{array}{l}\text { Effects of activities } \\
\qquad(\max ) \\
{[7]}\end{array}$ & \multicolumn{2}{|c|}{$\begin{array}{l}\text { Do annual statements of an organization or its } \\
\text { promotion materials disclose accurately effects of } \\
\text { activities undertaken by the organization in the } \\
\text { recent period? } \\
\text { (appraisal of the DM using scale } 0-3 \text { ) }\end{array}$} \\
\hline $\mathrm{f}_{13}$ & $\begin{array}{l}\text { Beneficiaries of } \\
\text { activities }(\max ) \\
{[7]}\end{array}$ & \multicolumn{2}{|c|}{$\begin{array}{l}\text { Do annual statements of an organization or its } \\
\text { promotion materials characterize thoroughly } \\
\text { beneficiaries of activities conducted by the } \\
\text { organization in the recent period? } \\
\text { (appraisal of the DM using scale 0-3) }\end{array}$} \\
\hline $\mathrm{f}_{14}$ & $\begin{array}{l}\text { Organization's } \\
\text { image (max); } \\
{[7]}\end{array}$ & \multicolumn{2}{|c|}{$\begin{array}{c}\text { Does the web-site of the organization help to } \\
\text { produce a positive image of the PBO? } \\
\text { (appraisal of the DM on scale 0-3) }\end{array}$} \\
\hline
\end{tabular}

Sources: [4], [6], [7], [9], [31], [34] and own elaboration

Table 2: PBOs performance assessment factors

Analysis has been conducted on the basis of the official and publicly available annual reports (from 2014) of the organizations considered. Criteria $\mathrm{f}_{11}-\mathrm{f}_{14}$ have been assessed by the article's authors, who played roles of potential donators. They have also determined weighting coefficients for the evaluation criteria (arbitrarily, using compromise). The model of preferences for the decision-making problem and measurement data are presented in the table included in Appendix. 
In turn, Table 3 provides a summary of the results received by applying the EVAMIX technique for mixed evaluations.

\begin{tabular}{|c|c|c|c|c|}
\hline \multirow{2}{*}{ No. } & \multicolumn{2}{|c|}{ United Kingdom } & \multicolumn{2}{c|}{ Poland } \\
\cline { 2 - 5 } & $\begin{array}{c}\text { Organization } \\
\text { (Charity) }\end{array}$ & $\begin{array}{c}\text { Appraisal } \\
\text { score }\end{array}$ & $\begin{array}{c}\text { Organization } \\
\text { (PBO) }\end{array}$ & $\begin{array}{c}\text { Appraisal } \\
\text { score }\end{array}$ \\
\hline 1 & UK A & 0.0112 & POL H & 0.0097 \\
\hline 2 & UK B & 0.0058 & POL D & 0.0082 \\
\hline 3 & UK D & 0.0053 & POL F & 0.0053 \\
\hline 4 & UK C & 0.0048 & POL A & 0.0035 \\
\hline 5 & UK E & 0.0018 & POL I & 0.0025 \\
\hline 6 & UK F & 0.0014 & POL G & -0.0005 \\
\hline 7 & UK H & -0.0141 & POL B & -0.0038 \\
\hline 8 & UK G & -0.0162 & POL C & -0.0119 \\
\hline 9 & & & POL E & -0.0130 \\
\hline
\end{tabular}

Source: own elaboration.

Table 3: Rankings of public service organizations obtained using the EVAMIX method for mixed evaluations

The higher the value of appraisal score is, the better is the performance of the public service organization from the point of view of decision-makers. Thus, the rankings of entities we have obtained show that the best organizations for donation, taking into account their effectiveness and reputation, are Charity $\mathrm{A}$ in the United Kingdom and PBO $\mathrm{H}$ in Poland. Charities B, D, C, E and F as well as PBOs D, F, A and I also turned out to be quite good solutions since the values of their appraisal scores are positive. On the other hand, neither Charity $\mathrm{H}$ nor PBOs G, B and C seem appropriate entities for supporting by the DMs examined since the values of appraisal scores determined for them are negative. The worst organizations for subsidizing in the UK and in Poland are Charity G and PBO E respectively.

\section{Conclusions}

In the article we have proposed a universal tool, based on the outranking MCDA methods (EVAMIX and EVAMIX with SD rules), namely EVAMIX for mixed (deterministic and stochastic) evaluations, which can be used to solve the problem of choosing public service organizations for subsidizing. In fact, applying this approach can enhance the evaluation process and improve decision-making since the assumptions on which it is based are in line with reality.

The procedure discussed can be applied in the case of public service organizations all over the world. The example presented in the paper may serve as a guide. 
Nonetheless, we have to remember that activity of such organizations may be assessed differently across countries taking into account 1) the tradition of the third sector in the economy, and 2) the level of development of social capital and the model of voluntary service (for example the engagement in voluntary service in Poland is very low comparing to Western European countries).

Furthermore, it has to be taken into consideration that reports of organizations of public benefit are not harmonized even in the European Union (for instance in Poland it is obligatory to present administrative costs and there is no such position in English reports; generally speaking, positions from Polish statements correspond to those from English reports but we cannot consider them as exactly the same as they may have different content), not to mention other countries. Thus, the measures considered in the analysis should certainly be tailored to each country's specific circumstances. However, bearing in mind trend of promoting accountability and transparency in the third sector organizations, above mentioned problems may be minimized in the future.

Finally, it cannot be forgotten that the tool proposed is only as good as the input data. Hence, the quality of information that is presented in financial statements and/or on the web pages is crucial and may constitute a restriction on the proposed approach application.

In our future work the focus will be on organizations of public benefit in other countries, for instance Canada and Australia.

\section{References}

[1] Barman, E. (2007). What is the Bottom Line for Nonprofit Organizations? A History of Measurement in the British Voluntary Sector. Voluntas, 18, 101115.

[2] Bullain, N. and Hadzi-Miceva, K. (2009). Study on Recent Public and SelfRegulatory Initiatives Improving Transparency and Accountability of NonProfit Organizations in the European Union. Contract number: JLS/D2/2007 /07. European Commission's Directorate-General Justice, Freedom and Security.

[3] http://apps.charitycommission.gov.uk/ShowCharity/RegisterOfCharities/Se ctorData/HistoricalData.aspx [Accessed 18/08/16].

[4] Charity Navigator - Your Guide to Intelligent Giving. Available at: http:// www.charitynavigator.org/index.cfm?bay $=$ content. view\&cpid $=2181$ [Accessed: 30/09/16].

[5] Chojnacka, E. and Górecka, D. (2016). Evaluating Public Benefit Organizations in Poland with the EVAMIX Method for Mixed Data. Multiple Criteria Decision Making, 11, 36-50.

[6] Dyczkowski, T. (2015a) Mierniki dokonań organizacji pożytku publicznego. Możliwości i ograniczenia stosowania (Performance Measures for Public Bene- 
fit Organizations. Opportunities and Limitations of Their Use - in Polish). Prace Naukowe Uniwersytetu Ekonomicznego we Wrocławiu, 398, 146-158.

[7] Dyczkowski, T. (2015b) Financial and non-financial information in performance assessment of public benefit organizations. Prace Naukowe Uniwersytetu Ekonomicznego we Wrocławiu, 398, 134-145.

[8] Figueira, J. and Roy, B. (2002). Determining the weights of criteria in the ELECTRE type method with a revised Simos' procedure. European Journal of Operational Research, 139(2), 317-326.

[9] Frumkin, P. and Kim, M.T. (2001). Strategic positioning and the financing of nonprofit organizations: is efficiency rewarded in the contributions marketplace?. Public Administration Review, 61(3), 266-275.

[10] Główny Urząd Statystyczny. (2015). Organizacje pożytku publicznego i 1\%. Notatka informacyjna (Public Benefit Organizations and 1\%. Central Statistical Office of Poland Information - in Polish). Available at: http:// stat.gov.pl/obszary-tematyczne/gospodarka-spoleczna-wolontariat/gospodar ka-spoleczna-trzeci-sektor/organizacje-pozytku-publicznego-i-1,4,2.html [Accessed 15/06/16].

[11] Górecka, D. (2010). Zastosowanie metod wielokryterialnych opartych na relacji przewyższania do oceny europejskich projektów inwestycyjnych (Applying multi-criteria methods based on the outranking relation to the evaluation of the European investment projects - in Polish). In: Nowak, M. (Ed.). Metody i zastosowania badań operacyjnych'10 (pp. 100-125). Katowice: Wydawnictwo Uniwersytetu Ekonomicznego w Katowicach.

[12] Górecka, D. (2011). On the choice of method in multi-criteria decision aiding process concerning European projects. In Trzaskalik, T. and Wachowicz, T. [Eds.]. Multiple Criteria Decision Making '10 -11 (pp. 81-103), Katowice: Publisher of The University of Economics in Katowice.

[13] Górecka, D. (2012). Sensitivity and robustness analysis of solutions obtained in the European projects' ranking process. In Trzaskalik, T. and Wachowicz, T. [Eds.]. Multiple Criteria Decision Making'12 (pp. 86-111). Katowice: Publisher of the University of Economics in Katowice.

[14] Górecka, D. (2013). Applying Multi-Criteria Decision Aiding techniques in the process of project management within the wedding planning business. Operations Research and Decisions, 22(4/2012), 41-67.

[15] Hadar, J. and Russel, W. (1969). Rules for Ordering Uncertain Prospects. American Economic Review, 59, 25-34.

[16] Hinkle, D. (1965). The change of personal constructs from the viewpoint of a theory of construct implications, Ph.D. Dissertation. Ohio: Ohio State University.

[17] Hokkanen, J. and Salminen, P. (1994). The choice of a solid waste management system by using the ELECTRE III decision-aid method. In Paruccini, 
M. [Ed.]. Applying Multiple Criteria Aid for Decision to Environmental Management (pp. 111-153). Dordrecht: Kluwer Academic Publishers.

[18] Hokkanen, J. and Salminen, P. (1997). Choosing a solid waste management system using multicriteria decision analysis. European Journal of Operational Research, 98(1), 19-36.

[19] https://www.gov.uk/search?q=charity [Accessed 16/09/16].

[20] Leshno, M. and Levy, H. (2002). Preferred by "All" and Preferred by "Most" Decision Makers: Almost Stochastic Dominance. Management Science, 48, 1074-1085.

[21] Leś, E., Nałęcz, S. and Pieliński, B. (2016). Third sector barriers in Poland. TSI National Report Series No. 7. Seventh Framework Programme (grant agreement 613034), European Union. Brussels: Third Sector Impact.

[22] McKeever, B. S. (2015). The Nonprofit Sector in Brief 2015. Urban Institute. Available at: http://www.urban.org/research/publication/nonprofit-sectorbrief-2015-public-charities-giving-and-volunteering [Accessed 17/09/16].

[23] Moore, D., Hadzi-Miceva, K. and Bullain, N. (2008). A comparative overview of public benefit status in Europe. International Journal of Not-for-Profit Law, 11(1), 5-35.

[24] Mousseau, V. (1995). Eliciting information concerning the relative importance of criteria. In Pardalos P. M., Siskos, Y. and Zopounidis, C. [Eds.]. Advances in Multicriteria Analysis (pp. 17-43). Dordrecht: Kluwer Academic Publishers.

[25] Quirk, J.P. and Saposnik, R. (1962). Admissibility and Measurable Utility Functions. Review of Economic Studies, 29, 140-146.

[26] Rhodes, Ch. (2015). Business statistics. House of Commons Library. Briefing Paper, 06152. Available at: www.parliament.uk/briefing-papers/sn06152.pdf [Accessed 17/09/16].

[27] Rogers, M. and Bruen, M. (1998). A new system for weighting environmental criteria for use within ELECTRE III. European Journal of Operational Research, 107(3), 552-563.

[28] Salamon, L. M. and Sokolowski, W. (2014). The third sector in Europe: Towards a consensus conceptualization. TSI Working Paper Series No. 2. Seventh Framework Programme (grant agreement 613034), European Union. Brussels: Third Sector Impact, 18-26.

[29] Spector, Y., Leshno, M. and Ben Horin, M. (1996). Stochastic dominance in an ordinal World. European Journal of Operational Research, 93, 620-627.

[30] Third Sector Impact. (2014-2019). Available at: http://thirdsectorimpact.eu /the-project/ [Accessed 16/08/29].

[31] Trussel, J.M. and Parsons, L. M. (2008). Financial reporting factors affecting donations to charitable organizations. Advances in Accounting, 23, 263-285.

[32] Voogd, H. (1982). Multicriteria evaluation with mixed qualitative and quantitative data. Environment and Planning B, 9, 221-236. 
[33] Voogd, H. (1983). Multicriteria Evaluation for Urban and Regional Planning. London: Pion.

[34] Waniak-Michalak, H. and Zarzycka, E. (2012). Performance measurement of public benefit organizations on the basis of information from financial statements and its influence on their results. Zeszyty Teoretyczne Rachunkowości, 68(124), 147-160.

[35] Waniak-Michalak, H. and Zarzycka, E. (2013). Czynniki wpływające na wybór organizacji pożytku publicznego przez darczyńców indywidualnych w Polsce - czy dane finansowe mają znaczenie? (Factors motivating individual donors to support public benefit organizations in Poland - does financial information matter? - in Polish). Zeszyty Teoretyczne Rachunkowości, 74(130), 91-108.

[36] Waniak-Michalak, H. and Zarzycka, E. (2015). Financial And Non-financial Factors Motivating Individual Donors To Support Public Benefit Organizations. Comparative Economic Research, 18(1), 131-152.

[37] Westall, A. (2009). Economic analysis and the third sector. Overview of economic analysis in relation to the third sector. Third Sector Research Centre. Working Paper No. 14.

[38] Żak, P. (2012). Public Benefit Status in Poland. Ogólnopolska Federacja Organizacji Pozarządowych. Public Benefit Status in V4 countries and Germany - conference in Prague 21.09.2012 Available at: http://ofop.eu/sites /ofop.eu/files/biblioteka-pliki/pzak_public_benefit_and_ngo_in_poland_ 20120921.pdf [Accessed 15/06/16]. 


\section{Appendix: Model of preferences and input data}

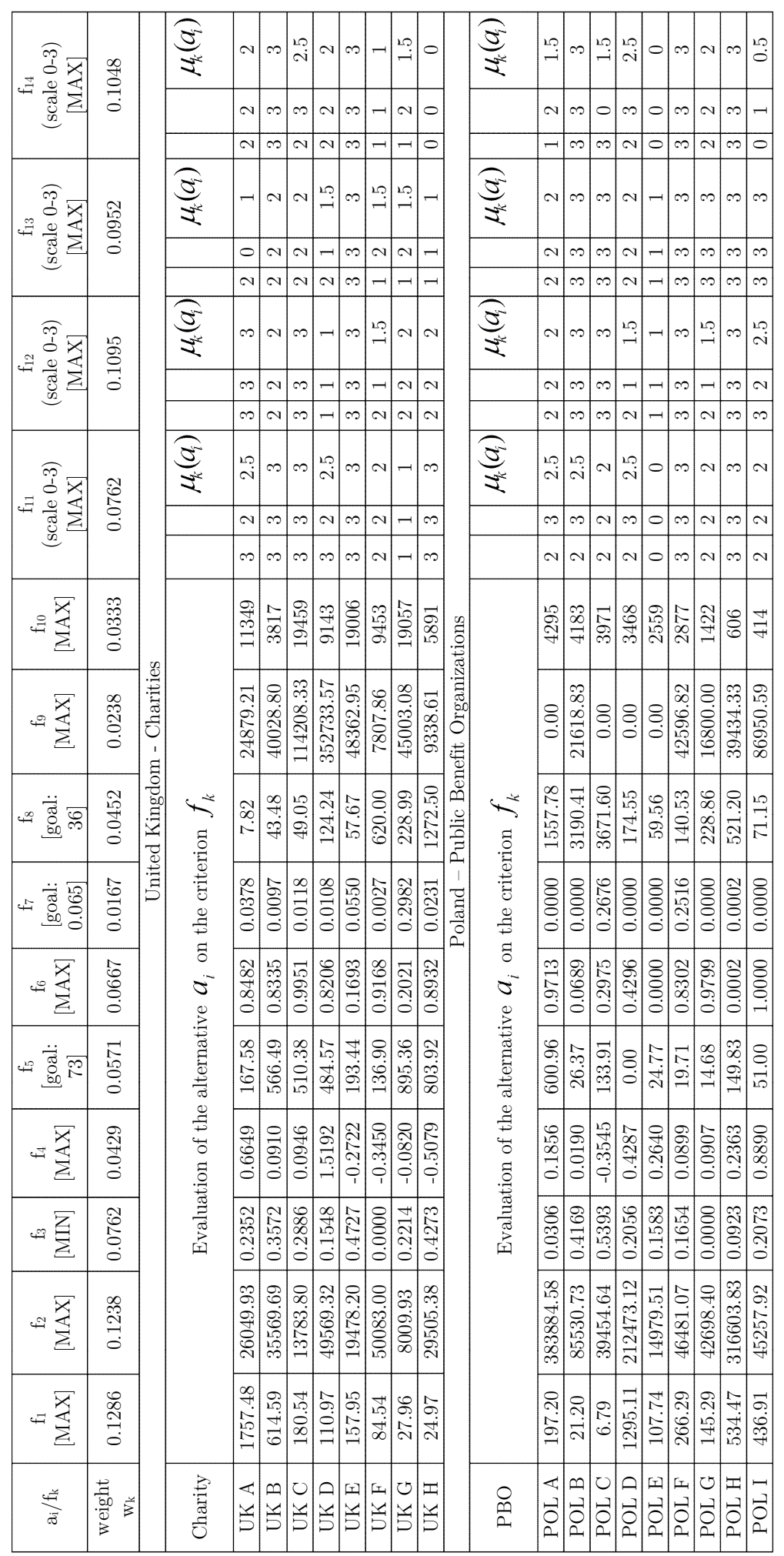

